\title{
Something for everybody
}

\section{Hannover}

THE world's largest and glossiest trade fair has become a supreme test of endurance. While the organizers boast of having crammed 60,000 cars into the car parks, yawning salesmen excuse themselves by saying they have just spent three hours in traffic.

Inevitably, innovation tends in these circumstances to be deeply buried in the products that people want to sell, preferably on the spot. But, after a week's spring sunshine, solar cells made of amorphous silicon abound, making enough electricity to circulate water in a toy swimming-pool or to light mock traffic lights. People like Interatom, a subsidiary of the nuclear energy constructor Kraft-Werke Union, say the opportunities for special uses are now rapidly increasing, the uneconomic character of solar cells notwithstanding.

Hannover's research ghetto, a building with the subtlety and floor-area of an aircraft hangar, is lavishly sprinkled with displays by West German universities of all kinds (of which there are three), most of them seeking industrial backing for research begun with public funds in academic laboratories. The phenomenon is partly instinctive and partly federal and local (Land) government policy. Industrial exploitation has become the watchword. (Some say it always has been.)

Academic stallholders hope to benefit in several ways. Professor Bert Küppers from the Fachhochschule at Aachen (a technical college not to be confused with the university at Aachen, called the Technische Hochschule) has a model of a generator capable of taking the variable-speed output from a windmill and producing constantvoltage $50 \mathrm{~Hz}$ current; if he is able to find a backer before the week is out, he will be in business.

Others look for industrial support to help win government grants. Professor Gerhard Müller from the Gesamthochschule at Essen, for example has developed a technique for coating objects made of materials such as plastic with metals of almost any kind. The principle is to use materials evaporated from an anode both as the working gas for a discharge and the coating substance. The development has cost the university less than DM 50,000 so far, but if the fair can recruit enough industrial testimonials, the chance of winning a big government grant will be bright.

On the biological front, pollution control and tree death are the prominent issues. The University of Oldenburgh has constructed a prototype of a self-contained system for processing sludge from sewage works which yields an oil-substitute rich in aromatic hydrocarbons and runs on energy by burning waste gases, so that the return of waste to the environment is kept to a minimum. (The one per cent of residue contains tightly-bound metals, which may yet be reclaimed.) This is a project supported so far by the government which now needs industrial support.

The Karlsruhe nuclear research centre is on a similar tack with a pilot plant for burning rubbish in a self-contained environment. Heat makes electricity, and waste acid gases in solution can be used in reclaiming heavy metals from the solid waste.

Tree death is West Germany's anxiety just now, with the lumber industry an important part of the agricultural economy. The University of Freiburg and the Karlsruhe centre (the Kernforschungszentrum) have both developed techniques for identifying damaged trees from infrared photographs, and the use of these methods has already helped to suggest the sources of damaging pollution on the Western edge of the Black Forest. And people are growing trees in controlled test chambers, as the Gesellschaft für Strahlen und Umweltforschung in Munich is eager to proclaim, so that the physiological and biochemical effects of the various pollutants can be investigated individually.

This is the plentiful small change of the research on display, which is most of all impressive for the diversity and ingenuity of the academics. At the other end of the scale, the major research establishments under the umbrella of the Arbeitgemeinschaft der Grossforschungseinrichtungen (big science spelled out) are also eager that passers-by shall recognize the useful things that they can do.

Radio-frequency resonators built as means of feeding power into particle accelerators (as at DESY, the Hamburg accelerator laboratory) are offered as being capable of other jobs. The Darmstadt laboratory (which accelerates heavy ions) also offers its beams as a way of punching micro-holes in pieces of material, if a little unconvincingly.

This group of a dozen national laboratories is exceedingly diverse and a little uncertain about its future. In the last year of the five-year government demand that spending should be reduced by 1.5 per cent a year, the organization has been cheered by the federal government's decision (see page 662) that Darmstadt should expand. But there is now some dismay that the umbrella organization should have been told, a few weeks ago, that it will have to make reductions of spending by differentiating among the twelve establishments, which range from the cancer research centre at Heidelberg to the national aerospace organization which is scattered over West Germany. People fear this new policy as a recipe for internecine strife in what was previously a selfcontented organization.
The federal minister for research and technlogy, Dr Heinz Riesenhüber, gave away nothing on the degree of economy expected when he popped in by helicopter last week. (Helicopters land in the car park, whence ministers are ferried between cars full of machine-gun-toting police.) The minister shook hands or patted heads as appropriate, and held a public long-distance conversation of conspicuous banality with the West German research station in the Antarctic before being whisked away.

The Antarctic programme is nevertheless big - the annual budget runs at DM 65 million a year. One of its more intriguing sets of observations is that of the tides on the ice shelf at the entrance to the Weddell Sea, from which it is hoped eventually to disentangle simple ocean tides and those affecting the floating ice.

Industrial research is prominent, although electronics research is curiously inconspicuous. (Nobody has a stand devoted to the making of silicon chips.) The West German love affair with the motor car is illustrated by the large crowds around the Mercedes-Benz and Volkswagen stands. Preussac, the minerals extraction company, has a vivid exhibition of ores dragged up from the sea-bed, but is not especially hopeful that it will make money from its interest.

For the rest, the fair's technology is a curious contrast between the machines with moving parts and those which seem to have none. (The halls housing the mechanical machines are, by comparison, as quiet as cathedrals.) This, no doubt, is one reason why the organizers think they can safely split the fair next year. Most machinerymakers show something very old Thyssen, for example, has a coal-burning locomotive outside its stand.

The computer people, by contrast, are all bustle. Apple, the US computer maker, has the best crowd-puller - it has simply provided 60 machines with which people can play if they fight their way to the head of the queue. Toshiba's illusionist is also a draw, but is there merely to suggest that his sponsors' photocopiers are magical. Given the time and energy, a person could decide which system will best meet his needs, although the computer-watchers are chiefly interested in computer-aided design and the like, which goes to show that this fair has become an essential part of West Germany's system of technical education.

Not everything is on this high plane. The lighting-hangar does give some manufacturers of specialized lighting systems a chance to show off, but it is mostly a display of lampshades of the kind that one might find (but would prefer not to find) in one's living-room. And an Australian company is selling (like "hot cakes") audio tapes of the sound of the ocean waves in which, it is said, there are hidden messages that will subliminally allow one to become better-adjusted in one of a dozen specific ways. How to live with traffic jams might be a good title for next year. 